\title{
LOVE OR MONEY? THE EFFECTS \\ OF OWNER MOTIVATION IN THE \\ CALIFORNIA WINE INDUSTRY
}

Fiona M. Scott Morton

Joel M. Podolny

Working Paper 6743

http://www.nber.org/papers/w6743

\section{NATIONAL BUREAU OF ECONOMIC RESEARCH \\ 1050 Massachusetts Avenue \\ Cambridge, MA 02138 \\ October 1998}

We thank John Roberts, Scott Schaefer, lunch participants at Stanford GSB, and seminar participants at Chicago GSB, Cornell University, and the NBER Summer Institute IO Meetings for helpful comments. We also thank the winery owners who shared their knowledge and insights with us. Research support for Fiona Scott Morton from the National Science Foundation, grant SBR9810178, through the NBER is gratefully acknowledged. The views expressed here are those of the authors and do not reflect those of the National Bureau of Economic Research.

(C) 1998 by Fiona M. Scott Morton and Joel M. Podolny. All rights reserved. Short sections of text, not to exceed two paragraphs, may be quoted without explicit permission provided that full credit, including (C) notice, is given to the source. 
Love or Money? The Effects of Owner

Motivation in the California Wine Industry

Fiona M. Scott Morton and Joel M. Podolny

NBER Working Paper No. 6743

October 1998

\begin{abstract}
Many industries are characterized by heterogeneous objectives on the part of firm owners. Owners of private firms, in particular, are likely to maximize utility, rather than profits. In this paper, we model and measure motivations of owners in on particular industry, the California wine industry. In both a formal model and an empirical analysis, we examine the implications of these motivations for market behavior. We find evidence that owners with strong non-financial motivations choose higher prices for their wines, controlling for quality; owners with strong profitmaximizing motives choose lower prices for their wines, controlling for quality. We also find that utility-maximizers are more likely to locate at the higher end of the quality spectrum, whereas profitmaximizers are more likely to locate at the lower end. We explore how the presence of a significant number of utility maximizers within an industry affects the competitive interactions within that industry. We conclude that some winery owners 'consume' features of their product or business as a substitute for profits and, in the process, provide softer price competition for for-profits. Additionally, in aggregate, their preference for quality can prevent entry into the high-quality segment on the part of profit-maximizing firms.
\end{abstract}

Fiona M. Scott Morton

Graduate School of Business

University of Chicago

1101 East 58th Street

Chicago, IL 60637

and NBER

fionasm@gsb.uchicago.edu
Joel M. Podolny

Graduate School of Business

Stanford University

Stanford, CA 94305-5015

fpodolny@lira.stanford.edu 


\section{Introduction}

When modeling firm behavior, economists typically assume that the objective of the firm is profit-maximization. There are two reasons for the prevalence of this assumption. First, more complex behavioral rules for firm behavior invariably reduce the parsimony, elegance, and analytical tractability of economic models. In particular, homogeneity of objective functions often makes analysis easier. However, this approach may preclude an interesting investigation of the implications of heterogeneity. Secondly, profit-maximization seems justifiable on evolutionary grounds. Because profit-maximization implies tremendous incentives to minimize costs, any firm that does not behave as if it is a profit-maximizer may not be able to survive in the long-run. While this evolutionary argument is not always explicitly invoked as justification for the assumption of profit-maximization, the essential claim has rich historical roots, dating back to the classic writings of such scholars as Smith, Marx, and Weber.

In this paper, non profit-related motives can raise a firm's costs or create inefficiencies. However, we claim, and provide evidence, that an owner's utility for the processes or features of the firm that generate these costs or inefficiencies can compensate for the lower financial rate of return. Essentially, we allow owners to maximize utility, rather than profits. Suppose a nonprofit-maximizing owner (hereafter labeled utility-maximizing owner) derives substantial utility from some facet of the firm other than the level of profits that the firm generates. For example, if the firm produces a high quality product, the owner may value the association with the product. Or, if the firm's activities further some social cause, the owner may derive utility from the cause's advancement. Perhaps the owner is simply motivated by the desire to provide kin with employment opportunities. Any such non-profit-related motives could adversely impact the costs or efficiency of the firm. Yet if the additional utility derived from the costly inefficient features of the firm is greater than the disutility from the lower rate of return, then the owner is willing to subsidize the firm and it can survive in the market.

Once the co-existence of profit and utility-maximizers is recognized, an interesting question arises: how do a significant number of utility-maximizers in an industry affect outcomes such as price, production, and quality levels? More generally, how do differing objectives among the types of owners affect competition? For example, in competitive markets, price represents the 
market value of the resources expended in producing the product, and in equilibrium entrants enter a market until economic profits are zero. However, these results may not obtain in industries with a significant numbers of utility-maximizers. Any change in entry choices of utility-maximizers is likely to affect the entry choices of rival profit-maximizers as well. In this paper, we attempt to gain insight into the market consequences of the co-existence of utility- and profit-maximizing firms by measuring the motivations of firm owners, discussing the type, extent, and implications of departures from the profit-maximization principle, and then empirically examining behavioral consequences of utility-maximization.

We begin with a data on prices and characteristics of California wines and supplement it with a survey of winery owners' attitudes towards their firm and product. We find that many of the people owning and running wineries in California have goals that depart from standard profitmaximization. Our model allows winery owners to care about the quality of their wine (separately from the effect of quality on profits) and to gain utility from lifestyle expenditures that raise production costs. Some winery owners are very rich and can afford to "consume" features of their wine or production process. Other winery owners are not rich, but make wine because of a love of the product and therefore are strongly affected by non-monetary considerations. Still other wineries are family businesses where whatever values the family holds may affect the way the business is run.

We find that owners that derive strong non-financial returns from ownership charge more for their product on a quality adjusted basis and locate at the higher end of the quality spectrum. These owners are unlikely to make the lowest-quality wine. Owners who primarily care about financial returns from their winery charge less for their product, conditional on quality, and are less likely to produce high-quality wine. However, a winery might want to produce a high-quality wine due to the externalities it creates for 'sister' bottles. We find that having a high-quality wine on sale at the same time as low quality wine from the same winery raises the retail price of the low quality wine.

One way to think about the preference of some owners for quality is that their total costs - financial and psychic - are lower than the costs of an identical profit-maximizing firm. The implications of strong quality preferences immediately follow: utility-maximizers will enter where they have a cost advantage, and the profit-maximizers have a disadvantage, at the upper 
end of the quality spectrum. If enough owners have resources to spend on their quality preference, they will drive out all profit-maximizers from the high quality segment by bidding up the rice of the input in fixed supply, high quality land. This will drive down the financial rate of recurn to producing that type of wine for any producer. Since the utility-maximizer gets a return from simply making quality, he is happy to remain in the segment despite the low financial return. ${ }^{1}$ The paper concludes that some winery owners 'consume' features of their product or business as a substitute for profits and, in the process provide softer price competition for forprofits. Additionally, in aggregate, their preference for quality can prevent entry into the highquality segment on the part of profit-maximizing firms

The wine industry is not the only one in which we expect a significant proportion of owners to have motivations for ownership other than profits. For example, opinion magazines, professional sports teams, films, art galleries, bars, and restaurants would also seem to be organizations where a large proportion of owners derive utility from some feature of the organization other than its level of profitability. More generally, it can be observed that firms whose owners potentially have motivations other than profit-maximization populate a significant fraction of the economy. As much as $80 \%$ of American business is privately owned in some way; "mom and pop" firms, family businesses, and larger private businesses form a significant portion of GDP and employment in the US. ${ }^{2}$ The owners of these businesses are not constrained by shareholders with a simple financial claim on the firm. Instead, one owner-manager or a family group owns the firm, and these owners maximize utility. Although an important component of their utility is likely to be profits, it seems reasonable to assume that owners have other arguments in their utility function besides profits. Thus, while our focus is on the wine industry, we believe that the findings of this paper have broader applicability.

\footnotetext{
' Our problem is also analogous to the compensating differential labor literature. Suppose the manager of the winery were an employee instead of the owner, but this manager still gained utility from expenditures $s$ and $t$. One possible contract the owners of the winery might choose is to allow the manager to make expenditures $s$ and $t$ and lower his wage by an amount that makes him indifferent to running the winery without $s$ and $t$. Such a firm would be maximizing profits, but might produce a different basket of products, for example, due to the particular preferences of the manager. Naturally, this sort of contract is limited by the initial wealth of the manager. Our set-up is slightly different in that the manager is the residual claimant and the supplier of capital to the firm. However, it is similar in that he is accepting a lower financial return in return for other benefits.

${ }^{2}$ The estimate that $80 \%$ of American businesses are privately owned comes from the Family Business Center at Loyola University (Steinberg 1996). This estimate is most likely conservative. Eddy (1996) includes estimates that as much as $90 \%$ of American business is private and as much as $40 \%$ to $60 \%$ of the U.S. Gross Domesic Product
} 
The remainder of the paper will proceed as follows. A review of the existing literature is in Section II; a discussion of the theoretical implications of this phenomenon is contained in Section III. Section IV describes the data and generates a basic model to predict price. In Section $\mathrm{V}$, we describe the survey we designed and administered and discuss the types of owners that seem to exist. Section VI tests the hypotheses generated earlier in the paper and Section VII concludes.

\section{Literature Review}

Our interest in the market consequences of different objective functions, some of which are not profit-maximization, is related to a number of distinct areas of research. For instance, there is a considerable literature on differences between for-profit and not-for-profit institutions such as hospitals and daycare centers. (See Rose-Ackerman (1996) for a survey of nonprofit organizations and economic theory.) Rose-Ackerman (1986) shows that nonprofit daycare centers produce high quality service, charge a low price and survive in a competitive market because of donations. Customers queue for the right to purchase the nonprofit product, while unmet demand patronizes the for-profit sector. According to Rose-Ackerman, the marginal firms are in the for-profit sector, which expands and contracts with demand, unlike the nonprofit sector. However, the two organizational forms do not always exhibit behavioral differences. A recent survey by Sloan (1997) concludes that for-profit and not-for-profit hospitals are operationally extremely similar, perhaps due to a dominant professional standard (medicine) and a dominant payor (the government). For-profits, however, are more likely to avoid locating in areas with an uninsured population. Lakdawalla and Philipson (1998) try to explain the share of an industry that chooses nonprofit status. In their setup, there is a limited supply of altruists in the world; altruists value the output of the firm as well as profits, while traditional firms only value profits. As the level of available economic profits drops, the altruists will give up the ability to distribute profits and choose to take nonprofit status because that frees up resources to increase output. They find support for the comparative statics of their model in the US long-term care industry.

comes from privately owned enterprises. Prince (1996) reports that as many as $95 \%$ of U.S. businesses are family 
Becker's (1957) theoretical work on discrimination in labor markets is also related to our interest in the market consequences of utility-maximizing firms. Becker allows employers (and consumers and employees) to have individual tastes for discrimination, rather than using the legal form of the organization to infer an objective function as the empirical work above does. Firms that have strong tastes for discrimination against a minority group will face a higher total cost of employing members of that group than firms that are not discriminatory. In Becker's model these low cost firms can drive firms with a taste for discrimination out of the market under some conditions. In Lakdawalla and Philipson (1998), Neary (1997), and our model, "altruists" can drive profit-maximizing firms out of the industry if there are enough of them to satisfy demand.

A second area of the literature that is closely related to our problem is analysis of workerrun firms. The classic choice of objective function for a firm owned by its workers is income per worker (Ward (1958)). When a labor-owned firm competes in a duopoly setting with a profitmaximizing firm, the standard duopoly equilibrium (Cournot or Bertrand) does not obtain because best-response functions have shifted or changed slope (Cremer and Crémer (1992)). Competition between the two types of firms also yields different operational choices for each. Futagami and Okamura (1996) show in a model that the labor-owned firm will use more capitalintensive technology and produce more output than the profit maximizing firm. Craig and Pencavel $(1996,1992)$ empirically examine worker-cooperative and profit-maximizing sawmills in the Pacific Northwest. They find that when output prices change cooperatives adjust wages more than for-profit firms do. Traditional for-profit corporations are more likely to adjust working hours or employment with the price of plywood.

While not the focus of this paper, there is a large area of the economics literature related to our problem, agency theory and managerial incentives. Managers have a legal obligation to maximize shareholder value, but may have personal incentives to deviate from profitmaximization. The agency literature is thus analyzing the effect of (a little bit of) utilitymaximization. In this paper we focus on owner-managers, who, in contrast, have no legal obligation to maximize profits, but may have no incentive to deviate from profit-maximization either. Empirical evidence of the existence of the agency problem is provided by Demsetz and

owned. 
Lehn (1985). As we do, they postulate that owners get 'amenities,' or increased utility, from owning sports and media companies that can substitute for financial returns. These amenities only arise if the owner can influence the way the firm is run, and therefore owners of these firms want close control. In their empirical work they show that this type of firm has more concentrated ownership structure than otherwise similar non-media and non-sports companies.

While these lines of research document or postulate the existence of organizations with objective functions that contain more than profits, or model competition between types, there is no work we know of that seeks to measure directly owner motivations within one industry and then relate these motivations to variations in market behavior. Our empirical work, motivated by the model below, seeks to accomplish this for the California wine industry

\section{Theory}

This section will address more specifically what winery owners might be including in their utility functions. There are two general types of inputs the owner may value: those that consumers also value, $s$, and those that consumers do not value, $t$. The most general example of the former would be quality, while an example of the latter might be an owner's hiring a winemaker who has a French accent and costs more, but is not better than other wine-makers. The latter case is simpler to analyze because the utility-maximizing owner's investment in $t$ does not alter the demand curve.

There are many tastes an owner could indulge that consumers of his or her wine would not value. For example, the owner could live the life of a landowner engaging in rural and social pursuits in the company of like-minded friends. Such an owner might tolerate some inefficiencies in running the winery that cater to that lifestyle, such as excessive care for the welfare of employees, not exerting enough effort to reduce costs, or continually interfering in the production process in a manner that raises cost. This could generate higher marginal costs, perhaps without any effect on quality at all. Suppose the owner's utility function is additive in profits and the benefits from using this particular type of input, $t$. The owner's utility has an additional term, $\alpha h(t)$, which represents the value of these benefits (h' $(t)>0$ and $\left.h^{\prime \prime}(t)<0\right)$. Profit-maximizers have 
$\alpha=0$ while utility-maximizers have $\alpha=1$. The cost of using input $t$ is $C(t)$, where $C^{\prime}(t)>0$ and $C^{\prime \prime}(t)>0$.

$$
U(p, t)=q(p) \cdot p+\alpha h(t)-C(q, t)
$$

Profit-maximizing owners choose $t=0$ because $t$ has a positive cost and brings no benefit that consumers value, hence it does not increase the owner's utility. However, the utilitymaximizing owner invests in input $t$ up to the point where marginal benefit equals marginal cost. Suppose that two owners have identical quality wines and face the same level and elasticity of demand. Wines are differentiated products and the utility-maximizing owner has higher marginal costs. The empirical implication of the model is that the utility-maximizing owner $(\alpha=1)$ will charge a higher price relative to the wine's merits and sell a smaller quantity than the profitmaximizing owner $(\alpha=0)$.

The other type of preference the owner might have, and be willing to pay for, is quality in and of itself. For example, wine can ferment in stainless steel tanks, American oak barrels, or French oak barrels. Barrels are much more expensive than steel tanks and are used for all good wine. French barrels $(\$ 700)$ make better wine than American barrels $(\$ 300)$, but the increase in quality is costly. ${ }^{3}$ We model the cost of quality by including an additional term in the cost function of the winery, $\mathrm{g}(s)$, that represents the benefits accruing to the owner from producing a given level of quality $s .\left(\mathrm{g}^{\prime}(s)>0, \mathrm{~g}^{\prime}(s)<0\right)$. Such an owner's utility function looks like:

$$
U(p, s)=q(p, s) \cdot p+\alpha g(s)-C(q(p, s), s)
$$

where, again, a profit-maximizing owner would have $\alpha=0$ and a utility-maximizer $\alpha=1$. Assume the demand curve for wine shifts out with increases in $s$. Both the profit-maximizing and utilitymaximizing owners may want to invest in some level of attribute $s$. The profit-maximizing owner will choose a level of quality, $s^{*}$, such that the marginal cost of quality is equal to the marginal financial return. Inputs that raise quality have a financial return, but when the owner gets both a

\footnotetext{
${ }^{3}$ Conversation with LeRoy McGinnis of McGinnis Wood Products, Inc., August 1998. The prices quoted are for premium barrels where the wood has air-dried for longer before being made into a barrel.
} 
financial and private return on the investment, he or she will invest more than is justified by the financial return alone. Technically, the owner's utility function $U(p, s ; \alpha)$ exhibits increasing differences (Milgrom and Shannon (1994)) in alpha; an increase in alpha raises the return to investment in quality. ${ }^{4}$ The empirical implication for these owners is that they will position their wineries at the higher end of the quality spectrum.

The activities of the winery owner may be a combination of those that increase quality and those that bring no benefit to consumers. For example, in the process of using fine material and human inputs $(s)$ he or she makes friends and contacts he or she most values $(t)$.

Expenditures of both types will be present in the utility function of the owner:

$$
U(p, s, t)=q(p, s) \cdot p+\alpha[g(s)+h(t)]-C(q(p, s), s, t)
$$

The owner then maximizes utility subject to a budget constraint, in the usual fashion. Very wealthy utility-maximizing owners may not be constrained by a budget, or its shadow price may be very small, and we would not expect profit-maximizing owners with access to capital markets to be constrained either. However, some utility-maximizing owners will have a limited stock of wealth to lose. The shadow price of the budget constraint reflects the marginal utility these owners would gain from additional resources. Modeling and collecting data on the wealth of winery owners and the amounts they choose to lose is beyond the scope of the current paper. 5

A question of interest is whether both the results of the simpler utility functions continue to be present in the case of the combined utility function. Is the quality-adjusted price of the utility-maximizer higher than that of the profit-maximizer and the quality choice of the utilitymaximizer higher than that of the profit-maximizer? The results will continue to hold if the utility function is supermodular, that is, if "increasing any subset of the decision variables raise[s] the incremental returns associated with increases in the others." ${ }^{\circ}$ If so, optimal price increases with expenditures on $s$ and $t$, while optimal quality choice increases with price and

\footnotetext{
${ }^{4}$ Increasing differences is defined in Milgrom and Shannon (1994) and explained as "increasing a parameter raises the marginal return to activities" page 164 .

${ }^{5}$ The wealth of current and potential utility-maximizing owners is very important for outcomes such as entry and resource prices in the industry. However, because macroeconomic conditions and many other forces affect people's stock of wealth and their willingness to lose money on a winery, we do not attempt to include a formal analysis of owners' wealth in the paper.
} 
expenditures on $t$. In this particular case, supermodularity depends on a strongly negative sign for the cross partial derivative of cost with respect to $s$ and $t$. This may not be a realistic assumption. ${ }^{7}$ However, supermodularity is not necessary (although certainly sufficient) for the relationships above to be true. The empirical section of the paper will settle these questions.

An important hypothesis we will not consider in our analysis is the role of price as a signal. The model would become much more complex if consumers of wine use price as a signal of unobservable quality. Therefore, we assume that there are enough knowledgeable consumers in the market and enough information on ratings and measures of quality that this effect may be safely omitted from the model. While a signal that alters consumer demand would affect the price set by both types of owners, the signal itself may also be an argument in the utility function of utility-maximizing owners. An owner may get pleasure from producing a "twenty dollar bottle of wine." Therefore, he may price the bottle above its quality level, or be overly optimistic about that quality level, in order to get the satisfaction of being known to produce high quality. If the wine market functions sufficiently well, however, such a price and the satisfaction that attends it would not be sustainable. Thus, we do not consider signaling in this paper.

Finally, a winery owner might also care about preserving a family tradition of owning and operating the winery in a certain way; beyond those particular concerns, the winery owner can maximize profits. The largest constraints on such an owner are likely to be to hire everyone in the family who wants a job at the winery, and not to raise capital in a way that would dilute ownership or control. ${ }^{8}$ The resulting behavioral difference between these owners and others will be that further investment would be productive, but is not being undertaken due to liquidity constraints. If such an owner values quality in and of itself, that preference may not appear in the quality of the wine produced because the owner is unable to invest in quality as much as he or she would like. ${ }^{9}$

\footnotetext{
${ }^{6}$ Milgrom and Shannon (1994)

${ }^{7}$ It is likely that the cross partial of cost with respect to $s$ and $t$ is negative. For example, it may cost less at the margin to find quality suppliers if the owner's expenditures on t create private benefits for both the owner and the high-quality suppliers he would like to use. However, this effect must be greater than dq/ds times the cross partial of cost with respect to $q$ and $t$ (which is likely to be substantial) in order for utility to be supermodular.

${ }^{8}$ National Public Radio California Report broadcast 5/17/97.

${ }^{9}$ Wineries are not tax shelters and never have been. However, before 1986 a vineyard was a tax shelter because it is agriculture. The farming cost of planting new vines could be immediately expensed, generating a loss for the vineyard that year even though the project as a whole might have positive net present value. The tax shelter reason
} 
The wine industry has an important characteristic: the highest quality grape-growing land, and therefore the highest quality grapes, are in fixed supply. Hobbyists may be able to drive down the financial rate of return to producing in the high-quality sector because they are willing to "overbid" for the fixed resource. ${ }^{10}$ An example of a resource that could be "overbid" is grapes; an average ton of Napa Chardonnay grapes cost $\$ 1,292$, while a ton of Chardonnay grapes from the Central Valley cost $\$ 521$ on average. "If utility-maximizers charge higher prices than their profit-maximizing rivals, one might expect the existence of utility-maximizers to attract entry from profit-maximizers. However, the effect of bidding for fixed inputs shows that this is not necessarily the case. Utility-maximizers can still make the segment inhospitable to profitmaximizers by driving up the cost of high quality production - in this case, land or grapes. The price of entering the segment becomes so high that, even given the state of competition, profitmaximizers do not wish to enter. Thus the two predictions of the model are not inconsistent with each other.

Though specific features of the wine industry differ from other industries where one might see utility maximization, some broad principles that affect all such industries can be noted. The attractiveness of an industry with non-financial benefits for owners who are profitmaximizers depends in part on the distribution of tastes across utility-maximizers and consumers. Suppose all utility-maximizers get positive utility from consuming the same attribute. If so, that part of product space will be crowded by hobbyist suppliers. If all consumers like the attribute too, then that same part of product space would normally be desirable for profit-maximizers. However, it may be sufficiently crowded with hobbyists that positive financial returns are not attainable. In contrast, if the attributes utility-maximizers like are spread out in product space, no one area may be inhospitable to profit-maximizers.

Additionally, profit-maximizers are better off if utility-maximizing owners get utility from attributes of the product or process that consumers do not value. For example, a daycare center run by an philanthropist might locate in a poor neighborhood. High income consumers do

\footnotetext{
for owning a vineyard has disappeared due to the tax reform act of 1986 . As far as we can tell there is not really a reason to think that marginal costs differ across firms for tax reasons, for example.

${ }^{10}$ Gallo's entry method into the high-quality segment provides support for this hypothesis. Gallo entered by purchasing land in Sonoma valley (a high-quality appellation) and using Alaskan pipeline earth moving equipment to reshape the hills into the best wine-growing configuration.

${ }^{11}$ The Final Grape Crush Report, 1988 crop. California Department of Food and Agriculture, Sacramento.
} 
not value this geographic location, so the philanthropist will not be competing against a for-profit daycare center. The for-profit daycare centers will locate where consumers are more affluent. Thus, owner preferences that consumers do not value will lower the revenues or raise the costs of the utility-maximizing firms and thereby constrain the ability of the utility-maximizers to compete effectively with the profit-maximizers. In the case of the wine industry, quality seems to be the attribute that is the most problematic for profit-maximizers since it is both popular among suppliers and valued by consumers; therefore, the empirical section of the paper will examine the quality location decision for both utility and profit-maximizers.

The arguments of the utility function are likely to be quite different in other industries where owners might maximize utility; we are not claiming that the specifics of the model above apply to art galleries or other utility-maximizing settings. For example, the owner of a magazine of opinion probably gets utility from higher circulation figures for the magazine. Similarly, a philanthropic inventor who gets utility from social surplus would want his or her invention disseminated to as many consumers as possible. We assume that quantity produced or sold is not an argument of a winery owner's utility function. Our interviews with owners did not ever indicate quantity was a goal. While an owner wants to make enough wine to supply the restaurants, competitions, friends, and fine wine distributors he is anxious to impress; beyond the small-scale production that can supply those parties, additional quantity does not increase private benefits.

\section{Data}

The data for this paper was collected by Beth Benjamin from the Bureau of Alcohol, Tobacco, and Firearms, Wines and Vines Buyers Guide, Connoisseur's Guide, and other industry sources. The dataset has complete information on California wines and wineries (see Benjamin (1994) for complete information regarding collection of this data). A bottle of wine is described by its price, the year it appears in Wines and Vines, vintage, grape varietal, the appellation on the label, the quality of the bottle and its vintage, whether it is ready to drink, and a variety of characteristics of the winery producing the bottle. The same bottle can appear in the data in more than one year; over time the bottle's price and some other characteristics (ready to drink, for 
example) may vary. Prices therefore belong to a bottle-calendar year combination, but the panel is not balanced. Price is taken from the Connoisseurs' Guide to California Wine; they report the suggested retail price of a bottle sold individually, not as a case, in a particular year in California. $^{12}$

A winery may produce many types of wine: wineries can produce different varietals under the same or different labels (brands) that may reflect a particular quality positioning. The winery can also make multiple products. Examples of popular products include table wine, dessert wine, sparkling wine, and brandy. The average cost of a bottle in the dataset is $\$ 9.50$; the minimum price is $\$ 2$. The group of wines in the $\$ 2-\$ 3.50$ range includes many varietals: red table wine, zinfandel, cabernet sauvignon, and chenin blanc are the most popular. The producers of these inexpensive wines include a range of producers such as Almaden, Beaulieu Vineyards, Fetzer, Gallo, Glen Ellen, and Paul Masson. The most expensive wine in the dataset is Stag's Leap cabernet sauvignon which cost $\$ 75$; other expensive wines in the dataset are produced by Heitz Cellar, Chateau Woltner, Caymus, and Silver Oak Cellars. See Table I for means and standard deviations of the variables in the wine dataset.

\section{Predicting the price of a bottle}

The first part of the empirical section develops a specification that predicts price; it will form the basis of later sections of the paper. We use the natural log of price as the dependent variable. Several categories of fixed effects must be included to pick up wine characteristics that strongly influence price. Varietal fixed effects control for different prices attached to different species of grapes. Grapes differ in their difficulty and cost of cultivation and also in their popularity. Vintage fixed effects are included because quality varies systematically across years, but is more constant within years. We also try a more complex specification that allows for additional separate vintage fixed effects for three of the most popular grape types: Chardonnay, Merlot, and Cabernet. However, varietal-specific vintage effects do not alter the results and so

\footnotetext{
${ }^{12}$ The Connoisseur's Guide's goal is to provide a price that will resemble what the reader encounters at the local wine store. The price they report is the actual price of the bottles they buy. Since the wines have just been released, they are not on sale. Occasionally, the Connoisseur's Guide buys a bottle at a "discount" store. in which case they do not use the discount price, but report the suggested retail price obtained from the winery. This winery suggested retail price is what a reputable wine store would usually charge.
} 
we report the simpler specification. Finally, there are of course year fixed effects to control for demand in any particular year.

One expects price to be driven primarily by the quality of the wine. Quality is measured on different dimensions by numerous variables in the dataset. The first quality variable is a numeric rating of bottle quality from the Wines and Vines Buyers Guide that is an integer between zero and three inclusive. Although this particular rating takes on only four values, we use it because of its complete coverage of varietals and the fact that blind testing determines the ratings. ${ }^{13}$ Secondly, the average quality rating of all the bottles produced by a winery over the previous three years is also constructed. Other important quality variables are status and three year average of winery status, which essentially measure the quality one would expect from the label. These were constructed by Benjamin and Podolny (1997) according to the deference ordering among the appellations used on the labels of bottles of wine produced in California. A higher status appellation is one that a winery chooses - over other options allowed by the grapes that compose the wine - to write on a label. ${ }^{14}$ Note that status is picking up other aspects of quality than those measured in the simple rating above; the correlation between status and quality rating is only 0.15 . However, over the longer term the two are more closely related; a winery's average quality over three years and the average status of its bottles over three years have a correlation coefficient of 0.59 . The age of a winery and longer term success with quality and status are also correlated with the export of wine; as their products become better, wineries are more likely to ship their products out of the country. Price and acreage are also included in the correlation matrix that forms Table II. The remaining quality variables include vintage and varietal, a rating of the vintage, whether the wine is drinkable, whether or not the wine is considered to have a tannic character, and whether the wine is irregular. Wines and Vines also notes if the wine is early maturing, whether the wine is available, and how ready it is to drink.

We would expect a winery's marginal cost to affect its choice of an optimal price for a bottle of wine. The most important determinant of costs observable to the econometrician is the scale of production. There are several variables in the dataset that proxy for winery size, although, unfortunately there is no direct measure of output or cases sold in a particular year.

\footnotetext{
${ }^{13}$ The tasters taste different wines of the same vintage and variety at the same time, but do not know the identities of individual bottles.
} 
Vineyard acreage, storage capacity, number of brands (e.g. Turning Leaf), and number of products (e.g. table, sparkling, dessert) all reflect size, and therefore economies on the manufacturing side. ${ }^{15}$ Additional economies of distribution are picked up in several distribution and wholesaling variables (e.g. wholesale, export) that indicate the firm has permission from ATF to ship the wine to different places

The effects of the variables on log price are reported in Table III. Because the quality rating variable takes on only four values, it is included as three separate quality dummies rather than as a continuous variable. The results are exactly what one would expect. Higher rated wines and higher status wines cost more. Drinkability raises price as does being less available (the wine is harder to get with a higher value on available). Irregular wines and those that will not keep (ready to drink) cost less. Ready to drink may also be picking up unobserved quality, since lower quality wines are not intended for storage and are always ready to drink. The cost variables are also significant and have the predicted signs. Wineries with distribution capabilities charge less as can be seen by the shipout coefficient. Larger vineyards measured in acreage, storage capacity, or number of brands charge less for their wines. The most expensive varietals include the most popular grapes, Cabernet, Chardonnay, Merlot, and some others such as Marsanne, Voigner, and Pinot Noir. Prices increase over the years in the dataset, particularly in the late 80's.

An interesting feature of the results is the importance of the age of the vineyard. The effect of age on pricing is quite robust and is shaped like a sideways, backwards "s." Prices increase steeply in age from zero up to ten or so, then there is a gentle dip that bottoms out at about 75 years, followed by an increase in price for older firms, catching up to the earlier peak at about age 120 . Very new firms have no reputation among consumers yet and appear to charge an "introductory" price to build demand; wineries ten years old or less charge less for a bottle conditional on quality and scale of operation. Firms in their prime -- those between ten and 50 years old -- have the highest prices.

\footnotetext{
${ }^{14}$ See Benjamin and Podolny (1997) for a detailed discussion of the construction of the status variables and their implications for price and the returns to investments in quality.

15 Note that a winery makes wine and a vineyard grows grapes. A winery can be vertically integrated, leading to the usual results on relationship-specific investment in grape-growing by the vineyard. A winery could instead have a long term contract(s) with vineyard(s) or purchase grapes of any quality on the spot market. Hence acreage may be correlated with production but is not necessarily an accurate sign of production levels.
} 
However, if the same regression is run on price data only from 1990, the importance of the age of the winery in predicting price vanishes, while the age effects remain unchanged using only 1983 price data. The results are therefore not an artifact of the time series nature of the data. Rather, it seems as if pricing in the early 80 s is somehow different from pricing in 1990. The height of hobbyist craze was the late 70s and early 80s. It may be the case that owners' goals changed over our sample period as the industry matured, the hobby became more expensive, or the next generation of owners turned out not have same preferences as their parents.

Note that in measuring economies of scale, simultaneity between price and quantity is not a problem because of the nature of wine production. The causality we are postulating is that large production quantities lead to lower costs which leads to a low price in order to stimulate sales. The obvious question is whether price has any causal effect on quantity - a likely scenario if the producer looks at market price before determining production quantities. Producers presumably do make choices based on current and expected prices, but by the time the wine is ready to be sold the demand curve has moved in unexpected ways (several years have gone by) and by then price cannot physically affect quantity provided. If any simultaneity remains, it is biasing the size coefficients in a positive direction (towards zero).

\section{Survey data}

To determine the motivations of the owners in our dataset, we mailed a survey to each winery in the dataset for which we could find an address. A copy of the survey is located in the Appendix. Approximately $13 \%$ of the wineries in the dataset were un-locatable; we searched in several data sources and if we could not find an address, that winery did not get a survey. We asked the owner or majority partner of the winery to fill out the survey and return it, which resulted in a total of 184 survey replies out of 411 mailed. Our response rate is therefore $45 \%$. Summary statistics for surveys turned in (including anonymous ones) follow in Table IV. We tried to construct questions that would get owners to quantify their non-monetary benefits and describe what kinds of things the non-monetary benefits are. The replies indicate there is a substantial amount of non-profit maximizing behavior going on in the industry. $78 \%$ of owners would be "somewhat" or "very" unlikely to sell their winery if they could get a higher return in 
the stock market. Almost $40 \%$ of respondents would lose over $\$ 10,000$ to improve the quality of their wines. Although almost all respondents aim to cover costs and earn some profit, less than half have a specific target rate of return in mind. The mean respondent does between a quarter and a half of his socializing with "wine people."

The significant correlations (see Table V) between variables include several for those who entertain widely. Entertaining is positively correlated with being willing to lose money to get quality, being less willing to sell for fair market value, feeling family ownership of the winery is important, having owned the winery for a longer amount of time, and not having a particular rate of return in mind. People who are willing to lose money for additional quality also entertain, don't want to sell their winery, and have more non-monetary reasons for owning the winery. Naming wines after the family is correlated with nothing except the length of time the winery has been owned by the family.

An owner's view of Gallo seems to do a good job of capturing his general type. Gallo is the largest winery in California and is known to be run in a professional manner that takes full advantage of it size and market power, although it is family owned. The vast majority of the wines and spirits they produce are quite low quality, although the firm does make some higher quality wines. Respondents who rate Gallo as 'a superior winery' have owned their wineries longer, have a particular target rate of return in mind, are not in the wine business for the lifestyle, and earn a significant portion of family income from their winery. Those who have owned their winery for a long time are also less apt to say they are in the business for "love of wine." Those who like Mondavi (a fairly large, family-run winery in Napa Valley that is widely regarded as one of the pioneers of fine wine-making in California) are similar to those who like Gallo; however, unlike the Gallo fans, they entertain a lot and feel it is important for their winery to stay in the family.

People who would invest more if they had more outside resources also socialize with wine people and have a unique non-financial reason for owning the winery. However, among those who do not like Gallo and have at least one non-financial motive for owning the winery, investing further if resources increase is correlated with the length of time the winery has been in the family. There may be a group of family-business owners who care about the quality of the product, but whose wealth has dissipated over time. 
We undertake a formal factor analysis to determine the relationships among the survey responses. Only one factor has an eigenvalue greater than one (1.08). This factor loads on the Gallo variable as well as longer ownership time, having a particular rate of return in mind and not being in the business for love of wine. This factor will be called the money factor and summarizes a profit-maximizing and businesslike attitude on the part of owners. The second factor is interesting (eigenvalue $=0.82$ ) because it is complementary. It loads on unlikely to sell the winery, importance of the winery staying in the family, in business for love of wine, and entertaining. We call this the love factor; it is clearly picking up owners who get substantial nonmonetary rewards from owning a winery.

The correlations among love, money, price, quality, and status are reported in Table Va. The largest correlation is between price and quality at 0.34 . The correlation between status and either price or quality is even lower at approximately 0.2 . Money is negatively related to all three variables and the love factor. The only surprising finding is the negative, though small, correlation between love and status (-.039).

Wineries that answered the survey clearly differ from wineries that did not. Principally, the non-respondents are bigger; the mean storage capacity for a respondent is 705 (thousand gallons) versus 2337 for the non-respondents. Kendall Jackson and Gallo did not fill out a survey. In terms of acreage, the respondents are actually somewhat bigger (333 versus 181). However, mean price and quality are almost equal across the two samples. Slight differences exist in status, age, and availability; respondents are higher status (.53 v .48), older (31 v 21$)$, and have slightly more available wine $(1.84$ v 1.93$)$. Distribution capabilities do not differ significantly across the two groups.

\section{Empirical testing}

Where should we expect to see the effect of owner motivation? The theory discussion above suggests that price and quality choices should both reflect the goals of the winery owner. In particular, our first hypothesis says that quality-adjusted prices should rise with the owner's private benefit parameter, $\alpha$. We expect that the answers to the survey questions contain information about each owner's $\alpha$ parameter. To capture the broad types of owners from the 
survey we include the love and money variables constructed from the factor analysis. The owner's concern for the wine's quality, process, and the owner's lifestyle (provided that lifestyle raises marginal costs) should increase prices. These attributes are reflected in the love factor. On the other hand, an owner with a businesslike attitude toward the winery is not concerned with quality and process beyond the level that is required to produce a competitive product.

Table VI reports the same price regression as Table III with the addition of love and money. We do not report the regression using the raw answers to the survey questions as the factors do a much better job explaining prices. As the theory predicted, those wineries scoring high on the love factor have higher prices, while those scoring high on the money factor have lower prices.

We are concerned that the love and money variables might be picking up unobserved quality, which should also affect price. In such a case, the estimated coefficient on love will represent unobserved quality correlated with love rather than the behavioral effect of those owners who love making wine. As noted in Table $\mathrm{Va}$, the correlation between love and price (a good proxy for quality) is 0.14 ; owners who love making wine make higher priced wines. Note that quality is well controlled for in the regression; we have the quality rating variable, status of the label, three-year quality of winery, three-year status of winery, vintage dummies, varietal dummies, tannic, and ready to drink, among other variables that all measure aspects of the quality of the wine.

In case there remains a problem with unobserved quality, we include several variables from the survey that are not components of love or money but will pick up any remaining unobserved quality. We also include interactions between these variables and financial resources to reflect the situation where the owner has a preference for quality and additionally has sufficient wealth to carry out that preference. The final columns of Table VI show regressions including the additional owner attitude variables and their interactions with the availability of financial resources. The coefficients on the variables will be positive if unobserved quality is present and these owner attitudes capture it. Only one coefficient is significantly positive; the others indicate that no further unobserved quality related to owner attitudes remains.

Importantly, the coefficients on the love and money factors are almost entirely unchanged and continue to be significant regardless of the specification in Table VI. We therefore believe 
that the love and money results are not due to the existence of unmeasured quality. Instead, there seems to be clear evidence that owners with strong non-financial motivations choose higher prices for their wines, controlling for quality. Conversely, owners with strong profit-maximizing motives choose lower prices for their wines, controlling for quality.

Moreover, we are also confident that there is sufficient product differentiation in the wine industry to sustain the behaviorally-induced differences in quality-controlled price. Indeed, the wine industry is an excellent example of a market in which small price differences (one standard deviation above the mean love factor for the average bottle results in a 30 cent premium) can be sustained in equilibrium due to heterogeneous tastes on the part of consumers for the wine, its label, the shape of the bottle, etc.. In the wine industry there is both vertical and horizontal differentiation. One of two bottles of the same quality level (no vertical differentiation) will generally be preferred by a consumer due to personal taste (horizontal differentiation). Because utility-maximizers are charging 'too much,' they must produce below the most efficient level or not sell all they are manufacturing and give away the excess to their friends and relations. ${ }^{16}$

\section{Quality Choice}

There are few exogenous features of a winery that predict quality, rather than being chosen simultaneously with it. As a consequence, the quality regressions reported in Table VII will be sparse. Bottle quality is postulated to be a function of varietal, vintage, and appellation. Clearly a winery has no control over the weather, and in the short run, particularly if it grows the majority of its own grapes, has less control over appellation and varietal selection. ${ }^{17}$ Winery age and age squared are also included as explanatory variables.

\footnotetext{
${ }^{16}$ An alternative explanation for the difference in the price chosen by utility-maximizers and profit-maximizers is that buyers know the attitude of the owner, and buyers place a higher value on wine produced by a utility-maximizer than a profit-maximizer. Perhaps consumers who themselves are wine lovers are happier spending money when the recipient of the money shares their values. In our view, such an explanation for the price difference is likely to apply to few consumers and few wineries since the explanation hinges on consumers having a relatively intimate knowledge of the motivations of individual owners. If there is any group of owners to which such an explanation would apply, we suspect that it is owners who frequently socialize with wine people. Since our survey identifies such owners, we included this variable in the analysis. If this alternative explanation is valid, the inclusion of this variable should reduce the effect of love on price. In fact, inclusion of this variable slightly increased the coefficient on love. Accordingly, we believe that this alternative explanation - while potentially valid in some cases - does not account for a significant proportion of the effect of love on price. .

${ }^{17}$ Even when a winery purchases its grapes from a grower in another appellation region, the contracts for such purchases are typically of at least a three-year duration. Therefore, even if a winery does not use its own grapes, there are some constraints on the ability to chose an appellation.
} 
Column one of the table includes answers to survey questions to see if these can predict bottle quality. If an owner is willing to lose money for quality, he or she makes higher quality wines. Similarly, those that are in the business for a love of wine and those that have made all the improvements they want to their winery make higher quality wine. Interestingly - but perhaps not surprisingly -- those who think Gallo is a superior winery choose to make lower quality wines. Vintage, varietal, and appellation dummies are largely significant. The adjusted $\mathrm{R}^{2}$ is not high, 0.083 , due to the shortage of explanatory variables. Specification two includes the love and money factors rather than the raw survey answers and confirms the previous results. The love factor significantly increases the likelihood that a particular bottle will be high-quality wine, while the money factor decreases it.

These results may be due to matching of high quality wineries and owners who love high quality in the property market, or may be due to owners who love wine working hard to improve whatever winery they happen to own. We are agnostic on that issue as it makes no difference to our hypothesis. In the case of purchase of the winery, the incremental price the utility-maximizer is willing to pay (above that of the profit-maximizer) can be treated as expenditure $s$. In this case, $s$ will increase fixed costs, and therefore total costs, but the implications of the model for quality choice are unchanged. We predict that owners who get substantial non-financial benefits from owning their own winery will choose to produce higher quality, whether they purchase the best wineries to get that higher quality, or whether they make expenditures of type $s$ once they own a winery.

We also examine the determinants of a winery's average, minimum, and maximum quality. The variables are defined for a particular vintage year belonging to a particular winery. Average quality is not weighted by volume or sales in any way since we do not have that information. Only vintage dummy variables are included since a winery's best or worst bottle in a given vintage could be one of a number of varietals or appellations. In these regressions each winery-vintage has only one observation, so the number of observations drops considerably. Average winery quality is again significantly affected by the love factor, but the money factor is insignificant, though of the correct sign. The relationship documented in columns two and three of Table VII can also be seen in the plot of average winery quality against money shown in Figure 1. There is a weak negative slope to the cluster of points. While the high quality and high money 
quadrant is relatively empty, there are many owners who do not care about profits but do not seem to be able to produce high quality either, weakening the relationship. Love is associated with high quality as can be seen in Figure 2. Here, as in the regression, the correlation between winery quality and owner motivation is stronger. Additionally, across all specifications older wineries produce lower quality products, although this pattern reverses for the very oldest wineries.

One might think a winery's minimum quality represents something about an owner's taste and his or her willingness to manufacture cheap products. Indeed, love is extremely significant in predicting the lowest quality a winery will manufacture, while money becomes insignificant. It seems that those owners with substantial private benefits from making wine are unwilling to make the lowest quality wines. The outcome is exactly reversed when predicting maximum winery quality. Love is insignificant in column 5, but having a high value of money seems to discourage an owner from producing high quality wines. A businesslike attitude about the winery is correlated with low owner interest in manufacturing the highest quality wines.

Recall that the preliminary conclusions above indicated that if there are enough utilitymaximizers in the industry who all want to produce high quality, they will drive down the returns to producing high quality wine. The findings just reported on the determinants of maximum winery quality support this conjecture. If the conjecture is true we should also see winery owners who are more indifferent to financial returns being more likely not to compete in the low-end segment. To test this proposition we focus on the survey questions that most closely pick up an owners attitude toward financial return. The question, 'Do you have a specific rate of return [for your winery] in mind?' is the best match for our problem. We also include 'how much money are you willing to lose to improve the quality of your wines?' and 'improvements would not be undertaken with more resources;' these questions both track the preferences of the owner for quality and also measure the extent to which the owner is willing to spend financial resources on quality.

Because we use many individual questions in this regression, including the love factor would be redundant. Instead, we include the four survey questions most highly correlated with love. These variables, in addition to the three questions mentioned above, are used to explain a 
winery's choice of minimum quality in a particular vintage year, and whether or not the winery chooses to make a wine of quality level zero, the minimum level.

The results are presented in Table VIII. Lack of concern for financial return significantly predicts the choice not to produce lower quality wines using two different specifications. The first column reports the results of an ordered probit on minimum winery quality whereas the second column shows the results of a standard probit where the dependent variable is a one if the winery chooses to make a wine of quality zero in that vintage. Being willing to lose money on quality and having undertaken all desired improvements also generally raise the minimum quality choice of the winery, as we also saw in Table VII. ${ }^{18}$

The implications of the dependence of quality choice on owner motivation are interesting. It appears that there are some competitors who will go into the high quality segment of the market; their $g(s)$ is a significant component of utility. They are not going to be stopped by the existence of profit-maximizers in that portion of quality space because some of them are rich enough to buy quality as a consumption good. Over-entry into the high-quality end of the spectrum lowers returns to producers of high quality wines. Thus, these utility-maximizers may unknowingly deter entry into the segment on the part of profit-maximizers. Profit-maximizers want financial returns and will be unwilling to stay in a low-return segment, even if it is the highquality segment.

Intuitively, the profit-maximizers most likely to remain in the high quality segment are those whose high quality wines create a positive externality for their lower quality wines. This positive externality should take the form of some kind of demand increase. One result of increased demand for lower-quality wines that have a higher-quality 'sister' should be higher prices. The price regressions of Table VI are repeated with the addition of variables reflecting sister externalities to see if this hypothesis is supported. The first specification includes the relative quality levels of sister wines on sale in the previous year. The variable is the difference between the maximum quality a winery sells in the previous year and the reference bottle. The variable is then divided into two, one variable for the positive and one for the negative range. As can be seen in Table IX, higher quality sister wines increase the market price of the reference

\footnotetext{
${ }^{18}$ The large positive demand shock for high quality wines in the late 80 's may have counteracted the crowding effect caused by utility-maximizing producers and raised the ex post return to producing high-quality wines. However, this
} 
bottle. However, surprisingly, lower quality sister wines that sit on the shelf prior to the reference bottle's sale have no effect on its price.

However, again, we are concerned that the 'sister' premium could be reflecting unobserved quality of the reference bottle. It is possible that a bottle is more likely to be somewhat underrated when the winery is capable of producing high quality that year. We try including two additional controls for unobserved quality. The first reflects a winery's capabilities in any given year by measuring the quality difference between the reference bottle and the maximum or minimum quality bottle produced by the winery in the same vintage. Columns two and three report the results of this specification and show that sister vintages have no effect on bottle price with or without other controls for unobserved quality. The second right-hand-side measure is the quality difference between the reference bottle and the winery's maximum or minimum quality bottle on sale in the same year. Although higher contemporaneous sister quality is also associated with a higher price, lagged sister quality retains its effect. Additionally, owner motivations continue to impact price; the money coefficient is smaller and not always significant; however, the love coefficient remains strong and significant across specifications.

The 'sister' premium is substantial (at the mean, approximately forty cents for each quality level difference) and could be a reason for a winery that primarily sells lower quality wines to continue to produce high-quality wines despite unremunerative direct financial returns. The indirect return will be largest for the largest wineries because the premium is earned on a greater volume of low quality wines. Additionally, large wineries are more likely to have distribution clout with supermarkets and other retailers that allows them to get a high-quality sister wine with very low volume onto the shelf where it can be seen by and influence consumers. The persistence of large, for-profit wineries in the high quality segment will further lower returns for utility-maximizing wineries and raise the price of the hobby for those owners.

\section{Conclusions}

In this paper we argue that non-profit-maximizing organizations should be observed in a market economy despite higher costs when those higher costs purchase some sort of non-

shock was unanticipated and, because our sample ends in 1990 , would only have affected prices for wines that had 
financial return for the winery owner. We examine the California wine industry because there is a great deal of scope for wineries to generate interesting components of the utility function that are not profits: for example, social status, lifestyle, community membership.

We hypothesize that there are two general types of inputs the owner may value: those that consumers also value (e.g. quality) and those that consumers do not value (e.g. a winemaker with a French accent). One interesting question is whether the existence of a large fraction of an industry choosing these inputs to maximize utility -- as distinct from profits -- has any effect on outcomes in the industry such as price, production, and quality levels. The implication of our model is that a utility-maximizing owner will charge a higher price relative to the wine's merits and will position his wine at the higher end of the quality spectrum.

We begin the empirical work with a simple model of bottle price that predicts most of the variation in price and produces the expected signs on all coefficients. Higher quality and higher status wines cost more. Wines with other positive characteristics cost more, while wines produced by larger wineries cost less. The most expensive varietals include the most popular grapes, Cabernet, Chardonnay, Merlot, and some others such as Marsanne, Voigner, and Pinot Noir.

Our survey of winery owners produces two important summary variables: love and money. The love factor is high for owners who would be reluctant to sell their winery, feel it is important for the winery to stay in the family, and are in the business for the love of wine. The money factor is high for winery owners who have owned their winery for a long time, admire Gallo, and have a particular rate of return goal for their winery. We find compelling evidence that owners with strong non-financial motivations choose higher prices for their wines, controlling for quality. On the other hand, owners with strong profit-maximizing motives choose lower prices for their wines, controlling for quality.

Our second conjecture is that those owners with strong non-financial motives will choose to produce higher-quality wines. We find that these owners do locate at the high end of the quality spectrum. A high value of the love variable significantly increases the likelihood that a particular bottle will be high-quality wine, while a high value of the money variable decreases it. Indeed, love is extremely significant in predicting the lowest quality a winery will manufacture, 
which we interpret to be an indication of the limited tolerance for producing bad wine by those in business for the love of wine. Money is highly negatively significant when predicting maximum winery quality, an indication that those motivated by business considerations do not enter the high-quality market segments.

If we are interpreting our results correctly, financial returns in the high-quality segment should be lower. The survey question regarding the lack of concern for financial return significantly predicts the choice not to produce lower quality wines. It appears that there exist some utility-maximizing competitors who will only enter the high-quality segment because they are rich enough to buy quality as a consumption good. Hobbyist entry into the high-quality end of the spectrum appears to have lowered (expected) returns to producers of high quality wines. We conclude that utility-maximizers are able to unknowingly deter entry into a desirable segment on the part of profit-maximizers. This is accomplished, despite soft price competition, by bidding for the best land, a fixed input of high-quality production. The supply response to higher demand is inelastic because the amount of appropriate land is fixed and converting existing land to grapegrowing takes several years. Profit-maximizers want financial returns and will be unwilling to stay in a low-return segment. However, we also find that a winery selling a higher quality 'sister' wine charges a slightly higher price for the reference bottle. The profitable positive externality generated by the higher quality wine may justify the continued presence of the multiproduct firm in the high-quality segment.

Our results have implications for several areas of the economics literature. Because we find that different types of owners systematically price differently and the type of owner is correlated with the quality of the wine, hedonic regressions of wine prices will not be correct. An ordinary hedonic pricing regression using data from wineries with different objective functions will consistently mis-specify the cost of the features of a high quality bottle of wine. Our results are also relevant for the traditional strategy literature; the classic strategy of moving first with a large capacity in order to deter entry by competitors will be more expensive and not work as well when those competitors are not maximizing profit. Another interesting area for thought and future research lies in how motives of subsequent generations of owners differ from the original owner and the implications for evolution of an industry. Utility-maximizing owners enter an industry because they receive substantial non-financial benefits. If those benefits are not as strong 
(regression to the mean) for subsequent owners then the objective function of the organization will revert to profit-maximization. This sort of pattern seems to describe entry in the software industry, for example, where founders have goals other than profit-maximization, but after selling to shareholders and professional management, the organization changes its behavior and maximizes profits.

The fact that utility maximizers have a lower threshold for profits has clear and important implications for the evolutionary argument to which we alluded at the outset. Rather than profitmaximizers driving utility-maximizers from the market or at least selected market segments, the utility-maximizers end up being more "competitive" than their profit-maximizing counterparts. An obvious extension of this empirical research is to actually undertake a dynamic analysis of the entry and exit of firms, incorporating the motivations of owners as the explanatory variables of central analytical interest. We suspect that such an analysis could be undertaken not only among the organizations in the wine industry, but also among organizations in other 'high status' industries, such as professional sports teams, thoroughbred horse racing, or exclusive restaurants.

We conclude that heterogeneity of objective functions among firms in an industry is important in understanding industry outcomes. In the wine industry we find that pricing and quality choice are affected by private preferences of owners. Distinct preferences on the part of utility-maximizing owners lead to different behaviors that, in turn, have important repercussions for profit-maximizing firms in the industry. It may not be the case that profit-maximizing firms can conduct their business 'as usual' in the presence of utility-maximizers; in the California wine industry, we see that price competition is softened and entry decisions are affected. A scarce resource (land) drives down the financial return to high quality so that profit-maximizing firms are kept out of popular (on the part of utility-maximizing owners) market segments. Identifying further effects of heterogeneity of objective functions should be an interesting area for future study. 
References:

Becker, Gary S. (1957) The Economics of Discrimination, University of Chicago Press, Chicago.

Benjamin, Beth A. (1994) Identity Construction Through Collective Affiliation. PhD Dissertation. Stanford University.

Benjamin, Beth A. and Joel M. Podolny (1997) "Social Order and Status in the California Wine Industry" RAND Corporation Working Paper.

Cremer, Helmuth and Jacques Crémer (1992) "Duopoly with Employee-Controlled and ProfitMaximizing Firms: Bertrand vs Cournot Competition" Journal of Comparative Economics: 16:241-258.

Craig, Ben and John Pencavel (1992) "The Behavior of Worker Cooperatives: The Plywood Companies of the Pacific Northwest" American Economic Review :82:5:1083-1105.

Demsetz, Harold and Kenneth Lehn (1985) "The Structure of Corporate Ownership: Causes and Consequences" Journal of Political Economy :93:6:1155-1177.

Eddy, Peg (1996) "Lessons, legends, and legacies: serving the family business" Journal of Financial Planning 9:76-79.

Futagami, Koichi, and Makoto Okamura (1996) "Strategic Investment: The Labor-Managed Firm and the Profit-Maximizing Firm" Journal of Comparative Economics:23:73-91.

Hayes, Rachel and Scott Schaefer, (1997) "How Much Are Differences in Managerial Ability Worth?" Kellogg School of Management working paper.

Lakdawalla, Darius and Tomas Philipson (1998), "Nonprofit Production and Competition," University of Chicago manuscript.

Milgrom, Paul and Chris Shannon (1994) "Monotone Comparative Statics" Econometrica: 62:1:157-180.

Neary, Hugh and David Ulph (1997) "Strategic Investment and the Co-existence of Labourmanaged and Profit-maximizing Firms" Canadian Journal of Economics:30:2:308-328.

Pencavel, John and Ben Craig (1994) "The Empirical Performance of Orthodox Models of the Firm: Conventional Firms and Worker Cooperative" Journal of Political Economy: 102:4:718-44.

Prince, Alan R. (1996) "Understanding the Eight Types of Business Owners" Trusts and Estates 135: 41-43 
Rose-Ackerman, Susan (1986) "Altruistic Nonprofit Firms in Competitive Markets: The Case of Day-Care Centers in the United States" Journal of Consumer Policy:9:291-310.

Rose-Ackerman, Susan (1996) "Altruism, Nonprofits, and Economic Theory" Journal of Economic Literature: 34:701-728.

Sloan, Frank (1997) "Commercialism in Not-for-profit Hospitals" working paper, Center for Health Policy, Research, and Education, Duke University.

Steinberg, Carol (1996) "The Next Generation" Success 43:85-88.

Stewart, Geoff (1991) "Strategic Entry Interactions Involving Profit-Maximizing and LabourManaged Firms" Oxford Economic Papers:43:570-583.

Stewart, Geoff (1992) "Management Objectives and Strategic Interactions among Capitalist and Labour-Managed Firms" Journal of Economic Behavior and Organization:17:423-431. 


\begin{tabular}{|l|r|r|r|r|r|r|r|}
\hline \multicolumn{7}{|c|}{ Table Ia. Summary Statistics } \\
Dataset of California Wineries \\
\hline & Survey Respondents & \multicolumn{4}{c|}{ Full Sample } \\
\hline Variable & Mean & Obs & Mean & \multicolumn{1}{|c|}{ Std. Dev. } & \multicolumn{1}{c|}{ Min } & Max & \multicolumn{1}{c|}{ Obs } \\
\hline price (nominal \$) & 10.7 & 4750 & 10.7 & 5.25 & 2 & 75 & 10079 \\
\hline quality & .604 & 4885 & .581 & .759 & 0 & 3 & 10341 \\
\hline 3-yr quality of winery & .440 & 4885 & .411 & .452 & 0 & 3 & 10341 \\
\hline rating & 58.0 & 4885 & 58.2 & 40.1 & 0 & 94 & 10341 \\
\hline status & .528 & 4885 & .501 & .416 & 0 & 1 & 10341 \\
\hline 3-yr status & .423 & 4885 & .388 & .402 & 0 & 1 & 10341 \\
\hline availability & 1.84 & 4885 & 1.89 & .810 & 0 & 3 & 10341 \\
\hline drinkability & 1.41 & 4885 & 1.40 & .685 & 0 & 3 & 10341 \\
\hline irregular & .252 & 4885 & .263 & .440 & 0 & 1 & 10341 \\
\hline ready to drink & .321 & 4885 & .319 & .466 & 0 & 1 & 10341 \\
\hline tannic & .034 & 4885 & .032 & .176 & 0 & 1 & 10341 \\
\hline wholesale & .788 & 4885 & .768 & .422 & 0 & 1 & 10341 \\
\hline ship out of state & .578 & 4885 & .527 & .499 & 0 & 1 & 10341 \\
\hline export & .349 & 4885 & .308 & .462 & 0 & 1 & 10341 \\
\hline number of brands & 1.47 & 4810 & 1.47 & 1.18 & 1 & 21 & 9885 \\
\hline number of products & 1.30 & 4861 & 1.35 & .856 & 1 & 10 & 10170 \\
\hline vineyard acreage & 333 & 4885 & 253 & 570.6 & 0 & 6401 & 10341 \\
\hline storage capacity & 705 & 4885 & 1,570 & 16,300 & 0 & 430,000 & 10341 \\
('000 gal) & & & & & & & \\
\hline age & 31.4 & 4269 & 28.8 & 33.3 & 1 & 158 & 8930 \\
\hline single owner & .489 & 4885 & .505 & .500 & 0 & 1 & 10341 \\
\hline multiple owners & .413 & 4885 & .386 & .487 & 0 & 1 & 10341 \\
\hline larger corporation & .136 & 4885 & .136 & .343 & 0 & 1 & 10341 \\
\hline
\end{tabular}

\begin{tabular}{|l|l|l|}
\hline \multicolumn{2}{|c|}{ Table Ib: Distribution of Observations across } \\
& \multicolumn{2}{|c|}{ Years } \\
\hline & $\begin{array}{l}\text { Survey } \\
\text { Respondents* }\end{array}$ & Full Sample \\
\hline 1981 & 443 & 1164 \\
\hline 1982 & 416 & 1089 \\
\hline 1983 & 194 & 489 \\
\hline 1984 & 349 & 838 \\
\hline 1985 & 489 & 1241 \\
\hline 1986 & 456 & 1066 \\
\hline 1987 & 534 & 1255 \\
\hline 1988 & 484 & 1093 \\
\hline 1989 & 388 & 940 \\
\hline 1990 & 548 & 1166 \\
\hline
\end{tabular}

* Survey respondents who report owning their winery in the relevant year. 


\begin{tabular}{|c|c|c|c|c|c|c|c|}
\hline \multicolumn{8}{|c|}{$\begin{array}{l}\text { Table II: Correlations between Variables } \\
(*=\text { significant at } 4 \% \text { level or better, } N=8850)\end{array}$} \\
\hline & Price & Quality & 3yr Quality & Status & 3yr Status & Acreage & Export \\
\hline Price & 1 & & & & & & \\
\hline Quality & $0.340^{*}$ & 1 & & & & & \\
\hline 3yr Quality & $0.352 *$ & $0.253^{*}$ & 1 & & & & \\
\hline Status & $0.165^{*}$ & $0.153^{*}$ & $0.143^{*}$ & 1 & & & \\
\hline 3yr Status & $0.263^{*}$ & $0.150^{*}$ & $0.585^{*}$ & $0.449^{*}$ & 1 & & \\
\hline Acreage & $-0.119^{*}$ & $-0.076^{*}$ & $-0.085^{*}$ & -0.018 & -0.006 & 1 & \\
\hline Export & $0.022 *$ & -0.011 & $0.074 *$ & $-0.032 *$ & $0.069 *$ & $0.115^{*}$ & 1 \\
\hline Age & $-0.131 *$ & $-0.083^{*}$ & $-0.110^{*}$ & 0.014 & -0.012 & $0.529^{*}$ & $0.048 *$ \\
\hline
\end{tabular}




\section{Table III: Regressions of Price on Wine and Winery Characteristics}

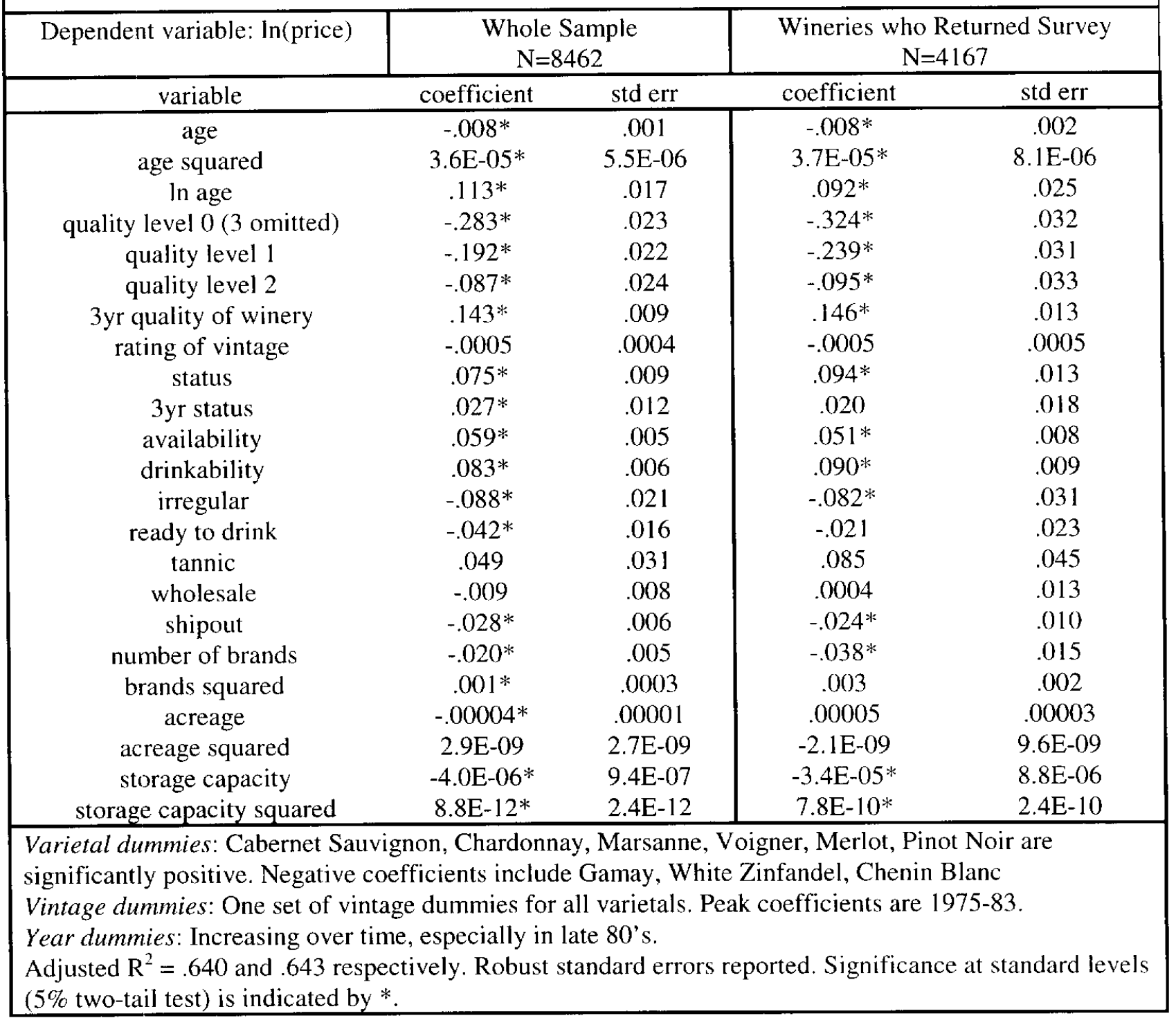


Table IV: Summary Statistics for Surveys

\begin{tabular}{|l|l|l|l|l|l|l|l|}
\hline$\#$ & question & $\begin{array}{l}\text { Upper } \\
\text { limit }\end{array}$ & obs & mean & std dev & min & max \\
\hline la & entertain- wine people & Never & 180 & 3.36 & 1.56 & 1 & 6 \\
\hline lb & entertain- non-profits & Never & 180 & 4.22 & 1.37 & 1 & 6 \\
\hline lc & entertain- business & Never & 180 & 4.24 & 1.65 & 1 & 6 \\
\hline 2 & lose \$ for quality & 1 million & 170 & 2.07 & 1.07 & 1 & 5 \\
\hline 3 & sell if higher return & Unlikely & 176 & 4.16 & 1.24 & 1 & 5 \\
\hline 4 & $\%$ wines family name & $100 \%$ & 176 & 2.97 & 2.23 & 1 & 6 \\
\hline 5 & invest more if richer & None & 177 & 2.19 & 1.12 & 1 & 4 \\
\hline 6 & $\%$ socialize w/wine & $100 \%$ & 178 & 4.12 & 1.37 & 1 & 7 \\
\hline 7 & years family owned & -- & 170 & 24.3 & 22.7 & 1 & 143 \\
\hline 8 & cover costs or profit? & Profit & 178 & 1.98 & .149 & 1 & 2 \\
\hline $8 \mathrm{~b}$ & target RoR? & No & 163 & 1.55 & .499 & 1 & 2 \\
\hline $9 \mathrm{a}$ & motivation-lifestyle & Yes & 181 & .558 & .498 & 0 & 1 \\
\hline $9 \mathrm{~b}$ & motivation-entertain & Yes & 181 & .077 & .267 & 0 & 1 \\
\hline $9 \mathrm{c}$ & motivation-community & Yes & 181 & .309 & .464 & 0 & 1 \\
\hline $9 \mathrm{~d}$ & motivation-love wine & Yes & 181 & .591 & .463 & 0 & 1 \\
\hline $9 \mathrm{o}$ & motivation-other & Wrote in & 181 & .448 & .499 & 0 & 1 \\
\hline $9 \mathrm{t}$ & total nonfinancial motives & Many & 181 & 1.98 & 1.32 & 0 & 5 \\
\hline 10 & important family owned? & No & 170 & 1.85 & 1.04 & 1 & 4 \\
\hline 11 & profits big part of income & Insignif & 174 & 2.36 & 1.38 & 1 & 5 \\
\hline $12 \mathrm{~g}$ & Gallo superior? & Yes & 165 & 5.92 & 2.56 & 1 & 10 \\
\hline $12 \mathrm{~m}$ & Mondavi superior? & Yes & 166 & 7.87 & 1.64 & 2 & 10 \\
\hline $12 \mathrm{~b}$ & Beringer superior? & Yes & 165 & 7.75 & 1.68 & 1 & 10 \\
\hline $12 \mathrm{~s}$ & Sutter superior? & Yes & 147 & 5.61 & 2.51 & 1 & 10 \\
\hline 14 & copy of survey results? & Yes & 173 & .86 & .353 & 0 & 1 \\
\hline & money factor & & 131 & .019 & .667 & -1.36 & 2.24 \\
\hline & love factor & & 131 & .014 & .672 & -1.52 & 1.19 \\
\hline & & & & & & \\
\hline
\end{tabular}




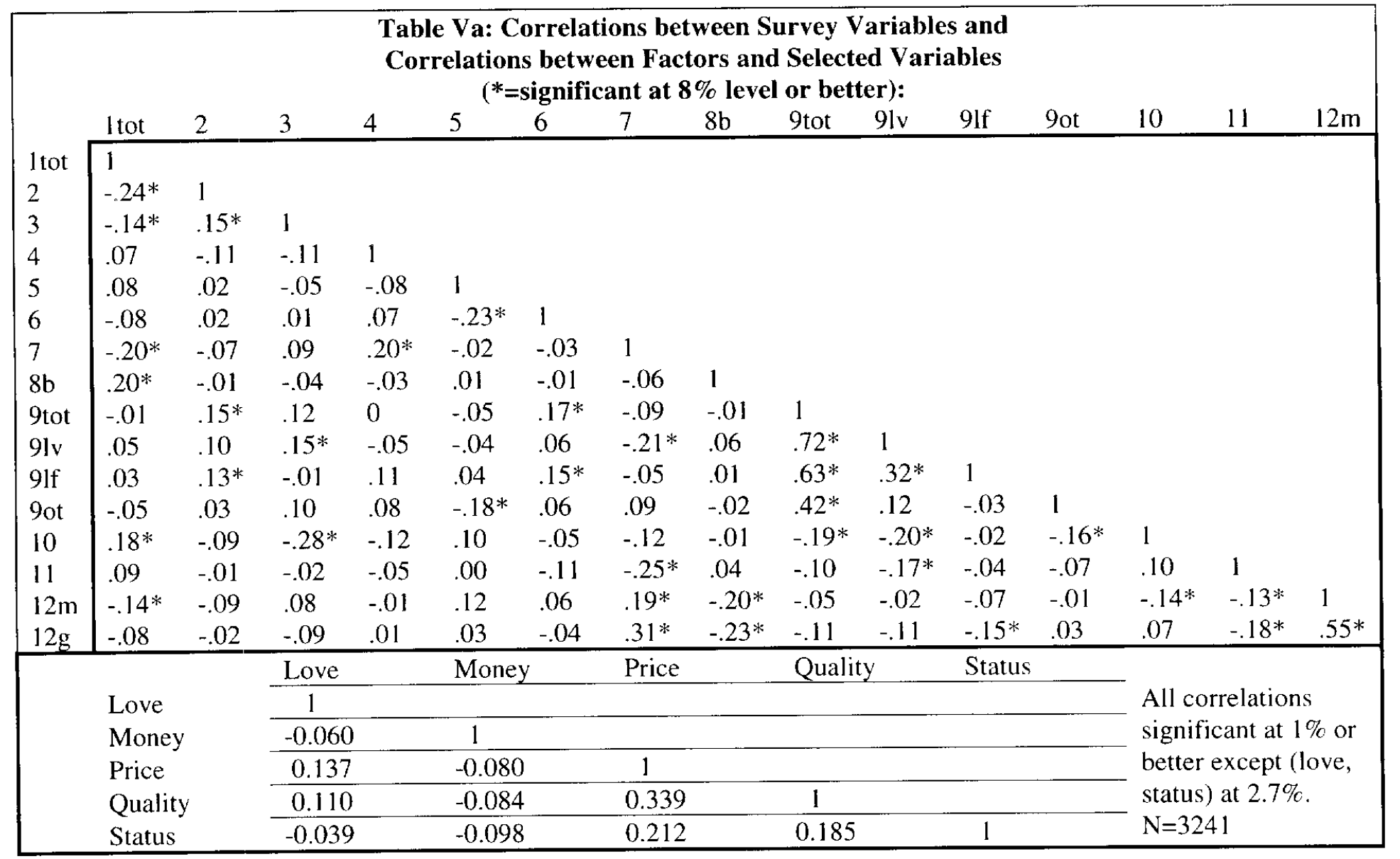

\section{Table Vb: Key for Table Va}

$\begin{array}{ll}1 \text { tot } & \text { Entertain business + entertain nonprofits + entertain wine people } \\ 2 & \text { willing to lose money for quality } \\ 3 & \text { unlikely to sell winery for fair value } \\ 4 & \text { Percentage of wines named after family. } \\ 5 & \text { Increases in resources would cause little additional investment in winery. } \\ 6 & \text { amount of socializing with wine people } \\ 7 & \text { length of time owned winery. } \\ 8 \mathrm{~b} & \text { no specific target rate of return in mind } \\ 9 \mathrm{tot} & \text { sum of motivations checked or written in. One point for each. } \\ 9 \mathrm{lv} & \text { Motivated by love of wine } \\ 91 \mathrm{f} & \text { Motivated by lifestyle } \\ 9 \mathrm{ot} & \text { other non-financial reason for owning winery written in. } \\ 10 & \text { Continuing family ownership of winery unimportant } \\ 11 & \text { winery profits small part of family income. } \\ 12 \mathrm{~m} & \text { Mondavi superior } \\ 12 \mathrm{~g} & \text { Gallo superior }\end{array}$




\section{Table VI: Regression of Log Price on Factors as well as wine and winery characteristics}

\begin{tabular}{|c|c|c|c|c|}
\hline Dependent variable: $\ln ($ bottle price $)$ & 1 & 2 & 3 & 4 \\
\hline Money Factor & $\begin{array}{l}-.0232 * \\
(.0090)\end{array}$ & $\begin{array}{l}-.0355 * \\
(.0092)\end{array}$ & $\begin{array}{l}-.0423 * \\
(.0098)\end{array}$ & $\begin{array}{l}-.0425^{*} \\
(.0097)\end{array}$ \\
\hline Love Factor & $\begin{array}{l}.0417^{*} \\
(.0090)\end{array}$ & $\begin{array}{l}.0398^{*} \\
(.0090)\end{array}$ & $\begin{array}{l}.0442^{*} \\
(.0092)\end{array}$ & $\begin{array}{l}.0446^{*} \\
(.0092)\end{array}$ \\
\hline $\begin{array}{l}\text { additional outside resources would } \\
\text { not result in more winery investment }\end{array}$ & --- & $\begin{array}{l}.0291^{*} \\
(.0056)\end{array}$ & $\begin{array}{l}.0355^{*} \\
(.0114)\end{array}$ & $\begin{array}{l}.0283^{*} \\
(.0057)\end{array}$ \\
\hline will lose money for quality & --- & --- & $\begin{array}{l}-.0047 \\
(.0107)\end{array}$ & $\begin{array}{l}-.0086 \\
(.0111)\end{array}$ \\
\hline $\begin{array}{l}\text { will lose money for quality*additional } \\
\text { resources no more investment }\end{array}$ & --- & -- & $\begin{array}{l}-.0035 * \\
(.0049)\end{array}$ & -- \\
\hline $\begin{array}{l}\text { will lose money for quality* winery } \\
\text { profits not part income }\end{array}$ & --- & -- & -- & $\begin{array}{l}-.0020 \\
(.0052)\end{array}$ \\
\hline winery profits not part income & --- & -- & -- & $\begin{array}{l}.0106 \\
(.0123)\end{array}$ \\
\hline Quality level 0 & $\begin{array}{l}-.3281^{*} \\
(.0381)\end{array}$ & $\begin{array}{l}-.3210^{*} \\
(.0384)\end{array}$ & $\begin{array}{l}-.3214^{*} \\
(.0384)\end{array}$ & $\begin{array}{l}-.3200^{*} \\
(.0384)\end{array}$ \\
\hline Quality level 1 & $\begin{array}{l}-.2467 * \\
(.0376)\end{array}$ & $\begin{array}{l}-.2430^{*} \\
(.0379)\end{array}$ & $\begin{array}{l}-.2447^{*} \\
(.0379)\end{array}$ & $\begin{array}{l}-.2433^{*} \\
(.0379)\end{array}$ \\
\hline Quality level 2 & $\begin{array}{l}-.0942^{*} \\
(.0406)\end{array}$ & $\begin{array}{l}-.0924^{*} \\
(.0409)\end{array}$ & $\begin{array}{l}-.0934 * \\
(.0409)\end{array}$ & $\begin{array}{l}-.0916^{*} \\
(.0408)\end{array}$ \\
\hline $\begin{array}{l}\text { Adj. } \mathrm{R}^{2} \\
\mathrm{~N}\end{array}$ & $\begin{array}{l}.660 \\
2637 \\
\end{array}$ & $\begin{array}{l}.663 \\
2637 \\
\end{array}$ & $\begin{array}{l}.663 \\
2637 \\
\end{array}$ & $\begin{array}{l}.663 \\
2637 \\
\end{array}$ \\
\hline $\begin{array}{l}\text { Dollar change in mean bottle price } \\
\text { when money or love factor increases } \\
\text { one standard deviation from zero. } \\
(-) \text { money factor } /(+) \text { love factor }\end{array}$ & $\begin{array}{l}-\$ 0.16 / \\
+\$ 0.30\end{array}$ & $\begin{array}{l}-\$ 0.25 / \\
+\$ 0.29\end{array}$ & $\begin{array}{l}-\$ 0.30 / \\
+\$ 0.32\end{array}$ & $\begin{array}{l}-\$ 0.31 \\
+\$ 0.32\end{array}$ \\
\hline
\end{tabular}




\section{Table VII: Ordered Probit Regression of Bottle and Vintage Quality (quality takes on four values only, 0-3)}

\begin{tabular}{|c|c|c|c|c|c|}
\hline Dependent Variable: & Bottle Quality & Bottle Quality & $\begin{array}{l}\text { Avg Winery } \\
\text { Quality }\end{array}$ & $\begin{array}{l}\text { Minimum } \\
\text { Winery Quality }\end{array}$ & $\begin{array}{l}\text { Maximum } \\
\text { Winery Quality }\end{array}$ \\
\hline Love Factor & -- & $\begin{array}{l}.296^{*} \\
(.047)\end{array}$ & $\begin{array}{l}.088^{*} \\
(.034) \\
\end{array}$ & $\begin{array}{l}.233 * \\
(.079)\end{array}$ & $\begin{array}{l}.012 \\
(.060) \\
\end{array}$ \\
\hline Money Factor & $-\cdots$ & $\begin{array}{l}-.090^{*} \\
(.038) \\
\end{array}$ & $\begin{array}{l}-.033 \\
(.031) \\
\end{array}$ & $\begin{array}{l}.105 \\
(.073) \\
\end{array}$ & $\begin{array}{l}-.207^{*} \\
(.057) \\
\end{array}$ \\
\hline $\begin{array}{l}\text { Willing to lose money } \\
\text { for quality }\end{array}$ & $\begin{array}{l}.095^{*} \\
(.020) \\
\end{array}$ & --- & -- & --- & --- \\
\hline $\begin{array}{l}\text { Own winery because } \\
\text { love wine }\end{array}$ & $\begin{array}{l}.244^{*} \\
(.049) \\
\end{array}$ & -- & $-\cdots$ & $\begin{array}{c}-- \\
\end{array}$ & --- \\
\hline $\begin{array}{l}\text { No further investment if } \\
\text { more resources }\end{array}$ & \begin{tabular}{|l|}
$.098 *$ \\
$(.021)$ \\
\end{tabular} & -- & --- & -- & --- \\
\hline $\begin{array}{l}\text { Think Gallo is superior } \\
\text { winery }\end{array}$ & \begin{tabular}{|l|}
$-.042 *$ \\
$(.011)$ \\
\end{tabular} & --- & -- & --- & --- \\
\hline Age & \begin{tabular}{|l|}
$-.015^{*}$ \\
$(.004)$ \\
\end{tabular} & $\begin{array}{l}-.009^{*} \\
(.004)\end{array}$ & $\begin{array}{l}-.009^{*} \\
(.003)\end{array}$ & $\begin{array}{l}-.031^{*} \\
(.009) \\
\end{array}$ & $\begin{array}{l}-.007 \\
(.006)\end{array}$ \\
\hline Age Squared & \begin{tabular}{|l|}
$9.5 \mathrm{E}-05^{*}$ \\
$(2.9 \mathrm{E}-05)$ \\
\end{tabular} & \begin{tabular}{|l|}
$5.0 \mathrm{E}-05$ \\
$(3.1 \mathrm{E}-05)$ \\
\end{tabular} & $\begin{array}{l}5.7 \mathrm{E}-05^{*} \\
(1.9 \mathrm{E}-05) \\
\end{array}$ & $\begin{array}{l}.00020 * \\
(.00007) \\
\end{array}$ & $\begin{array}{l}3.6 \mathrm{E}-05 \\
(4.5 \mathrm{E}-05)\end{array}$ \\
\hline Varietal dummies? & Yes & yes & No & no & no \\
\hline Vintage dummies? & Yes & yes & Yes & yes & yes \\
\hline Appellation dummies? & Yes & yes & No & no & no \\
\hline $\begin{array}{l}\text { Pseudo } \mathrm{R}^{2} \\
\text { Observations }\end{array}$ & $\begin{array}{l}.085 \\
3195 \\
\end{array}$ & $\begin{array}{l}.082 \\
2608 \\
\end{array}$ & $\begin{array}{l}.065 \\
811 \\
\end{array}$ & $\begin{array}{l}.069 \\
811 \\
\end{array}$ & $\begin{array}{l}.033 \\
811\end{array}$ \\
\hline \multicolumn{6}{|c|}{$\begin{array}{l}\text { The sample in columns } 1 \& 2 \text { is bottle quality of respondents who owned their winery for the relevant } \\
\text { observation. Average, minimum and maximum winery qualities are defined within a vintage. In columns } 3-5 \\
\text { each winery-vintage combination that responded to the survey and owned the winery within three years after the } \\
\text { vintage has one observation in the sample. }\end{array}$} \\
\hline
\end{tabular}


Table VIII: Financial Concerns Explain Choice to Produce Low Quality

\begin{tabular}{|l|l|l|}
\hline Dependent Variable: & $\begin{array}{l}\text { Minimum Winery } \\
\text { Quality }\end{array}$ & $\begin{array}{l}\text { Winery Produces 0-level } \\
\text { Quality? }\end{array}$ \\
\hline No Specific Rate of Return in & $.238^{*}$ & $-.238^{*}$ \\
Mind & $(.103)$ & $(.107)$ \\
\hline Willing to lose money for & .040 & -.018 \\
quality & $(.045)$ & $(.047)$ \\
\hline No further investment if more & $.182^{*}$ & $-.197^{*}$ \\
resources & $(.043)$ & $(.046)$ \\
\hline Entertains &. .044 & .035 \\
& $(.031)$ & $(.032)$ \\
\hline Unlikely to sell winery & $.107^{*}$ & $-.103^{*}$ \\
& $(.046)$ & $(.047)$ \\
\hline Important winery remains in & .014 & -.002 \\
family & $(.049)$ & $(.051)$ \\
\hline Own winery because love wine & .080 & -.027 \\
& $(.103)$ & $(.107)$ \\
\hline Age & $-.040^{*}$ & $.040^{*}$ \\
& $(.009)$ & $(.010)$ \\
\hline Age Squared & $2.6 \mathrm{E}-04^{*}$ & $2.5 \mathrm{E}-04 *$ \\
& $(7.3 \mathrm{E}-05)$ & $(7.4 \mathrm{E}-05)$ \\
\hline Vintage dummies? & yes & yes \\
\hline Pseudo R & .102 & .106 \\
Observations & 905 & 911 \\
\hline range of dependent variable & $0-3$ & 0 or 1 \\
\hline $\begin{array}{l}\text { Minimum winery quality is defined within a vintage. Each winery-vintage combination } \\
\text { that responded to the survey and } \\
\text { the sample. * indicates significance at the 5\% level or less. }\end{array}$ \\
\hline
\end{tabular}


Table IX: Regression of Log Price on Sister Wine Variables as well as Wine, Winery, and Survey Characteristics

\begin{tabular}{|c|c|c|c|c|}
\hline Dependent Variable: $\ln$ (bottle price) & 1 & 2 & 3 & 4 \\
\hline Sister wine of higher quality last year & $\begin{array}{l}.0387^{*} \\
(.0091)\end{array}$ & $\begin{array}{l}.0368^{*} \\
(.0095)\end{array}$ & $\begin{array}{l}.0358 * \\
(.0095)\end{array}$ & $\begin{array}{l}.0341^{*} \\
(.0094)\end{array}$ \\
\hline Sister wine of lower quality last year & $\begin{array}{l}-.0039 \\
(.0196)\end{array}$ & $\begin{array}{l}-.0070 \\
(.0197)\end{array}$ & $\begin{array}{l}-.0037 \\
(.0194)\end{array}$ & $\begin{array}{l}.0014 \\
(.0202)\end{array}$ \\
\hline $\begin{array}{l}\text { Sister wine of higher quality this } \\
\text { vintage }\end{array}$ & -- & $\begin{array}{l}.0072 \\
(.0090)\end{array}$ & $\begin{array}{l}.0062 \\
(.0090)\end{array}$ & --- \\
\hline $\begin{array}{l}\text { Sister wine of lower quality this } \\
\text { vintage }\end{array}$ & --- & $\begin{array}{l}.0107 \\
(.0155)\end{array}$ & $\begin{array}{l}.0144 \\
(.0155)\end{array}$ & --- \\
\hline Sister wine of higher quality this year & $\cdots$ & --- & --- & $\begin{array}{l}.0237^{*} \\
(.0090)\end{array}$ \\
\hline Sister wine of lower quality this year & --- & --- & --- & $\begin{array}{l}-.0008 \\
(.0156)\end{array}$ \\
\hline Money Factor & $\begin{array}{l}-.0103 \\
(.0101)\end{array}$ & $\begin{array}{l}-.0089 \\
(.0102)\end{array}$ & $\begin{array}{l}-.0296 * \\
(.0108)\end{array}$ & $\begin{array}{l}-.0265^{*} \\
(.0125)\end{array}$ \\
\hline Love Factor & $\begin{array}{l}.0454^{*} \\
(.0099)\end{array}$ & $\begin{array}{l}.0459^{*} \\
(.0100)\end{array}$ & $\begin{array}{l}.0501 * \\
(.0101)\end{array}$ & $\begin{array}{l}.0492 * \\
(.0118)\end{array}$ \\
\hline $\begin{array}{l}\text { additional outside resources would } \\
\text { not result in winery improvement }\end{array}$ & -- & --- & $\begin{array}{l}.0245^{*} \\
(.0061)\end{array}$ & $\begin{array}{l}.0244^{*} \\
(.0063)\end{array}$ \\
\hline willing to lose money for quality & --- & --- & $\begin{array}{l}-.0166^{*} \\
(.0059)\end{array}$ & $\begin{array}{l}-.0098 * \\
(.0061)\end{array}$ \\
\hline Quality level 1 & $\begin{array}{l}-.3711^{*} \\
(.0665)\end{array}$ & $\begin{array}{l}-.3611^{*} \\
(.0717)\end{array}$ & $\begin{array}{l}-.3334^{*} \\
(.0716)\end{array}$ & $\begin{array}{l}-.3821 * \\
(.0723)\end{array}$ \\
\hline Quality level 2 & $\begin{array}{l}-.2621^{*} \\
(.0527)\end{array}$ & $\begin{array}{l}-.2549^{*} \\
(.0549)\end{array}$ & $\begin{array}{l}-.2387^{*} \\
(.0548)\end{array}$ & $\begin{array}{l}-.2676^{*} \\
(.0555)\end{array}$ \\
\hline Quality level 3 & $\begin{array}{l}-.0906^{*} \\
(.0460)\end{array}$ & $\begin{array}{l}-.0874 * \\
(.0463)\end{array}$ & $\begin{array}{l}-.0792 * \\
(.0466)\end{array}$ & $\begin{array}{l}-.0932 * \\
(.0474)\end{array}$ \\
\hline $\begin{array}{l}\text { Adj. } R^{2} \\
N\end{array}$ & $\begin{array}{l}.663 \\
2229\end{array}$ & $\begin{array}{l}.663 \\
2229\end{array}$ & $\begin{array}{l}.667 \\
2229\end{array}$ & $\begin{array}{l}.666 \\
2138\end{array}$ \\
\hline \multicolumn{5}{|c|}{$\begin{array}{l}\text { The increase in the mean bottle price when higher sister quality goes from zero to one is approximately } \\
\$ 0.40 \text {. If maximum sister quality is two levels higher than the reference bottle, the price increase is } \\
\text { about } \$ 0.80 \\
\text { The sample is respondents who owned their winery for the relevant observation. All explanatory } \\
\text { variables from Table II are included in the regression but coefficients not reported in the interests of } \\
\text { space. * indicates significant at the } 5 \% \text { level, two-tail test. }\end{array}$} \\
\hline
\end{tabular}


Figure 1

Average Quality of Winery's Product Plotted Against the Money Factor (one point for each respondent)

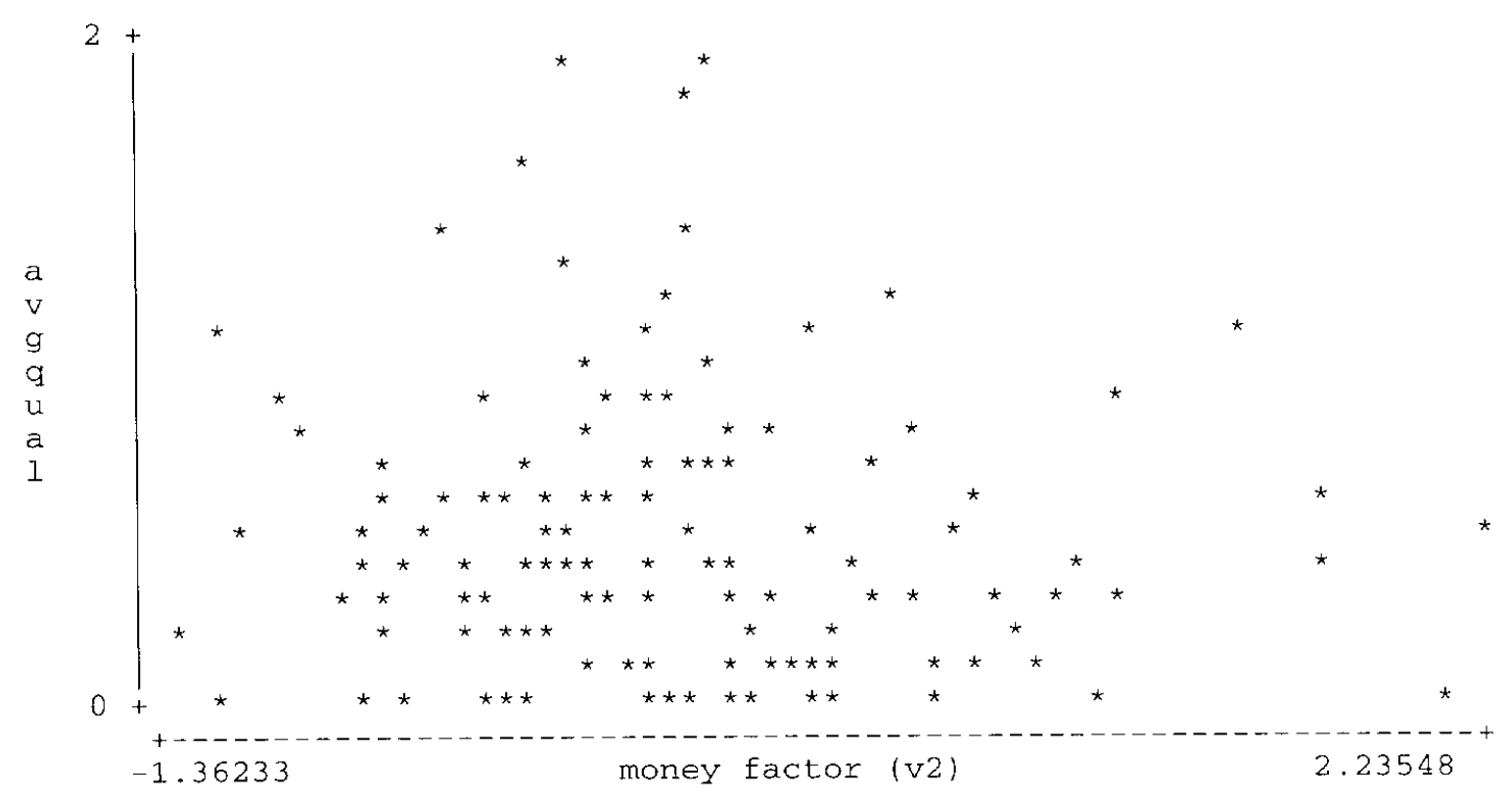

Figure 2

Average Quality of Winery's Product Plotted Against the Love Factor (one point for each respondent)

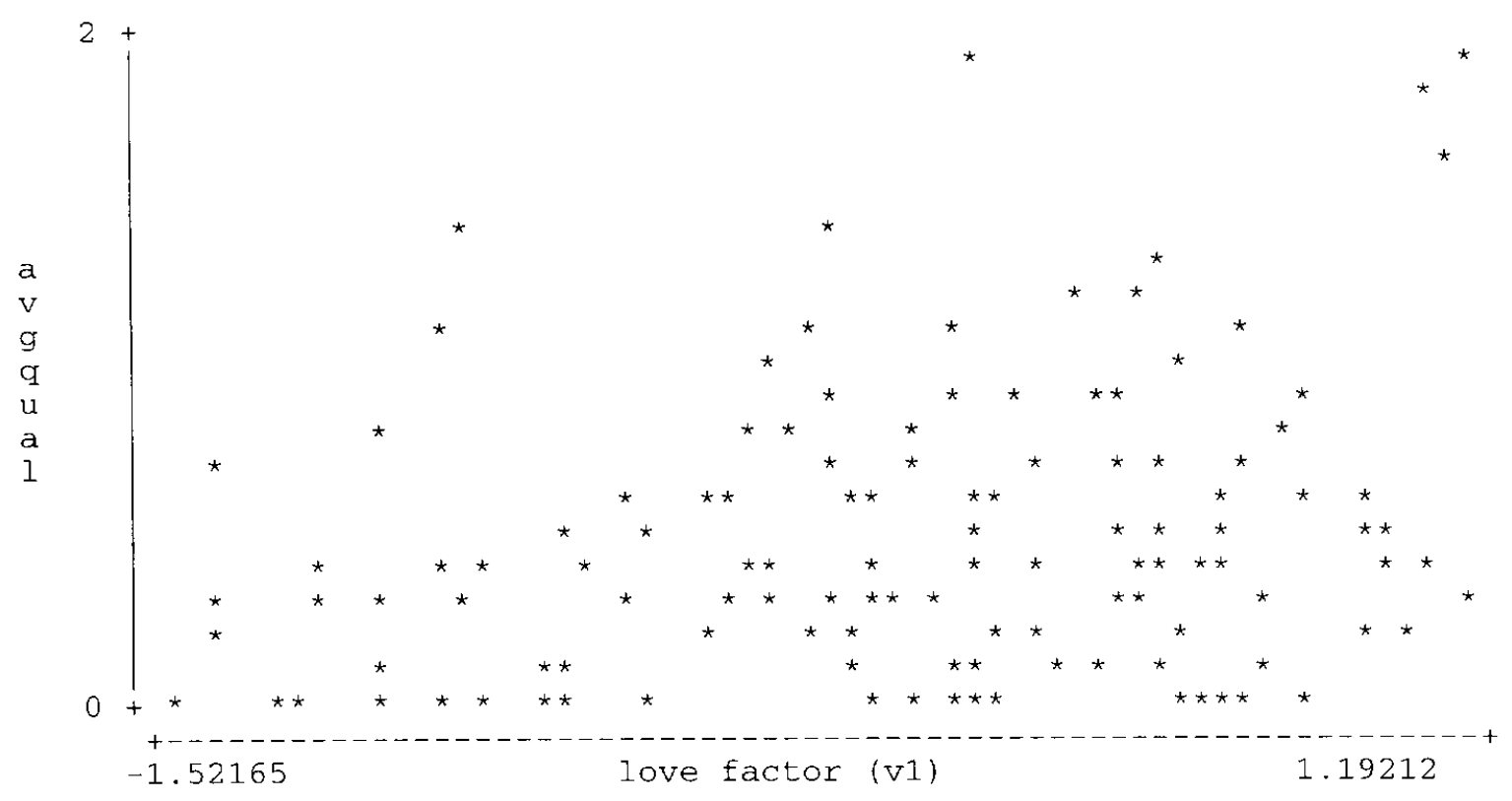




\section{Stanford Business School Survey of Winery Owners}

Name of respondent

Title and Winery Name:

Please provide current responses to the questions if your views have changed over time.

1. How often does your winery provide activities or a site for entertaining (either individually or in groups)?

a) members of the wine community? (e.g growers, producers, buyers, service providers)

at least several times a week

several times a month

once a month

several times a year

once a year

never

b) on behalf of local groups or non-profit organizations?

at least several times a week

several times a month

once a month

several times a year

once a year

never

c) non-wine related business associates? (e.g. business lunches, meetings, events)

at least several times a week

several times a month

once a month

several times a year

once a year

never

2. Suppose that someone develops an innovation that would significantly improve the quality of the wines that you produce but is so costly you would lose money by purchasing the innovation. (The price of the innovation is greater than the improvement in wine quality is worth in the marketplace.) How much money would you be willing to lose on the investment in order to significantly improve the quality of your wines?

None

between $\$ 1$ and $\$ 10,000$

between $\$ 10,000$ and $\$ 100,000$

between $\$ 100,000$ and $\$ 1,000,000$

more than $\$ 1,000,000$

3. Suppose you were offered a fair market value for your vineyard in cash and you knew you could earn a higher rate of return in the stock market. How likely is it that you would sell? 
Very likely

sornewhat likely

neither likely nor unlikely

somewhat unlikely

very unlikely

4. Approximately what percentage of your wines are named after your family?

Less than $10 \%$
$10 \%-25 \%$
$26 \%-50 \%$
$51 \%-75 \%$
$75 \%-99 \%$
$100 \%$

5. If your income or revenue from non-winery resources were suddenly bigger (times 10, for example) how much additional investment or improvements to your winery would you undertake?

significant additional investment or improvement some additional investment or improvement a little additional investment or improvement additional resources would have no effect on winery investment or improvement

6. Which category below best reflects the percentage of your socializing in the last six months that has been with "wine people" and wine-related people?
none
less than $10 \%$
$10 \%-25 \%$
$26 \%-50 \%$
$51 \%-75 \%$
$75 \%-99 \%$
$100 \%$

7. How long have you or your family owned your winery? years

8. What are your financial goals for your winery?
a) cover costs
b) cover costs and earn some profit

If you answered b), do you have a rate of return in mind? yes no

If so, what rate of return are you happy achieving?

9. Sometirnes people have non-financial motives for owning a winery. Circle any of the following non-financial motives that are important to you.

lifestyle associated with owning a vineyard being part of the wine community entertaining for non-wine-related business 
love of wine

Are there any other important reasons why you own your vineyard?

10. How important is it to you that your winery continue to be owned by a member of your family?
very important
somewhat important
not very important
completely unimportant

11. How would you characterize the importance of your winery's profits? Profits from your winery are?

your most important source of family income

a significant source of family income

part of family income

a small part of family income

do not contribute to family income

12. We would now like you to briefly consider what it means to be a superior winery. Please evaluate the following wineries on a 10 point scale as to how well each meets your definition of a superior winery, where a ' 1 ' denotes a poor or inferior winery and a 10 denotes an outstanding or superior winery.

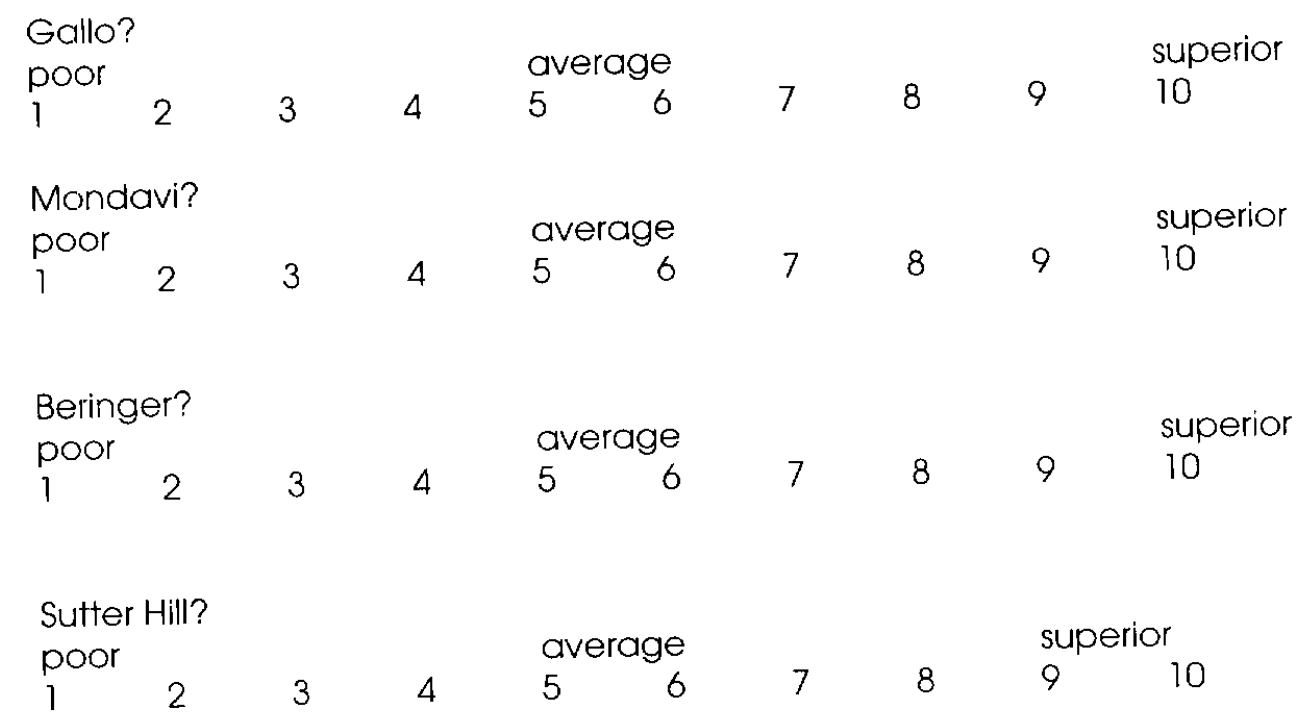

13. If your views on the above questions - particularly questions 8 and 9 -- have changed significantly over the time you have owned your winery, please let us know how (with approximate dates).

14. Would you like to receive a comparison of your survey responses to those of your peers in the industry?

Yes No 